\title{
Contribution of calcium in drinking water from a South American country to dietary calcium intake
}

\author{
Gabriela Cormick ${ }^{1,2^{*}}$, Mercedes Lombarte ${ }^{3}$, Nicole Minckas ${ }^{1}$, Andrés Porta ${ }^{4}$, Alfredo Rigalli ${ }^{3}$, Jose M. Belizán ${ }^{1}$, \\ Natalia Matamoros ${ }^{5}$ and Maela Lupo ${ }^{3}$
}

\begin{abstract}
Objective: To describe the calcium concentration of tap and bottled waters from Argentina and to estimate the contribution of drinking water to calcium recommendations.

Results: Calcium concentrations provided by water authorities ranged from 6 to $105 \mathrm{mg} / \mathrm{L}$. The mean calcium level of samples analysed at the Laboratorio de Ingeniería Sanitaria, National University of La Plata was 15.8 $(S D \pm 13.2) \mathrm{mg} / \mathrm{L}$ and at the Bone Biology Laboratory of the National University of Rosario was $13.1( \pm 10.0) \mathrm{mg} / \mathrm{L}$. Calcium values of samples from supply systems and private wells was similar. Most bottled waters had calcium levels well below $50 \mathrm{mg} / \mathrm{L}$. The intake of one litre of drinking water from Argentina could represent in average between 1.2 and $8.0 \%$ of the calcium daily values for an adult.
\end{abstract}

Keyword: Bottled water, Calcium intake, Drinking water

\section{Introduction}

The amount of calcium in drinking water is variable, it can range from negligible levels to values higher than those contained in several dairy products, this variability depends on the origin, treatment received and distribution system [1, 2]. Data from Canada and the United States of America show that the average calcium concentration in tap water varies between 6.8 to $135 \mathrm{mg} / \mathrm{L}$ [3]. Also, a study conducted in Spain registered values of calcium in tap water ranging from 0.5 to more than $200 \mathrm{mg} / \mathrm{L}$ [4]. Higher values of 64 to $523 \mathrm{mg} / \mathrm{L}$ were published in another study conducted in Algeria [5]. The amount of ionic calcium in commercially bottled water is also variable and levels of calcium can reach more than $400 \mathrm{mg} / \mathrm{L}[6]$.

\footnotetext{
*Correspondence: gabmick@yahoo.co.uk

${ }^{1}$ Department of Mother and Child Health Research, Institute for Clinical Effectiveness and Health Policy (IECS-CONICET), Emilio Ravignani 2024, Buenos Aires, Argentina

Full list of author information is available at the end of the article
}

Calcium in water is basically found in its ionic form (soluble calcium), which enhances absorption in the gastrointestinal tract [7]. Pooled data from 4 studies shows a mean absorbability ratio for calcium in water and in milk of $1.084 \pm 0.043$ [2]. With this high bioavailability, water consumption could improve daily calcium intake and contribute to meet daily recommendations [8].

An adequate calcium intake is important for the prevention of hypertension, preeclampsia and for bone health maintenance $[9,10]$. It has also been associated with the reduction of renal stones, increased body mass index, insulin resistance and colorectal cancer [11-15].

Calcium intake is inadequate in several regions of the world. In spite of the well-known benefits of calcium intake on the prevention of preeclampsia, pregnant women in LMICs show values well below recommendation [20-23]. In Argentina, the 2005 National Nutrition and Health Survey (ENNyS) showed that more than $94 \%$ of women and about half of children age 2 to 5 years do not reach values of adequate intake [24, 25]. However, 
the survey did not assess water intake so calcium intake could be higher than that reported.

Data published on the mineral content of water in Argentina is scarce, as quality control does not require analysis of calcium [26]. Some food composition tables only have commercially bottled water information while others do not report any type of water $[27,28]$. The objective of this article is to describe the level of calcium of tap water samples supplied by municipal pipelines of different localities of Argentina as well as of bottled waters commercially available in the country. The secondary objective is to estimate the contribution of drinking water from Argentina to calcium intake recommendations.

\section{Main text \\ Methods}

We contacted provincial water authorities of Argentina to obtain data on the calcium content of tap water and reported the values provided by each authority. In addition, we obtained information from tap water samples from different municipalities of the country remitted to the Bone Biology Laboratory of the National University of Rosario (UNR) and the Laboratorio de Ingeniería Sanitaria, National University of La Plata (UNLP). All samples were obtained from drinking tap water that was either from private wells or from water supply systems. Water from private wells was defined as groundwater of different depths pumped into a private dwelling. Water supply systems were defined as water provided by local authorities, obtained from groundwater or superficial water that received different treatment procedures before distribution.

The calcium concentration of water samples remitted to laboratories was measured using techniques according to Standard Methods for the Examination of Water and Wastewater [29].

Water samples at the UNR were determined by atomic absorption spectroscopy (Arolab MK II, Buenos Aires, Argentina), by direct aspiration into acetylene-oxygen flame and absorbance at $424.0 \mathrm{~nm}$. Calcium concentration was determined by comparison with a standard solutions of calcium (1-100 $\mathrm{mg} / \mathrm{L}$ ) processed simultaneously and in the same way, with a relative error of $0.5 \%$ and a relative standard deviation of $5.2 \%$.

Calcium concentration of water samples at the UNLP was determined according to the titration method with ethylenediaminetetraacetic acid (EDTA). Water samples were diluted in a sodium hydroxide solution to produce a $\mathrm{pH}$ of $12-13$ at which magnesium largely precipitates as the hydroxide. EDTA $0.01 \mathrm{M}$ was added as titrant reagent until the Eriochrome Blue Black R indicated all calcium has been complexed. This methodology has the capacity to determine calcium content from $2 \mathrm{mg} / \mathrm{L}$ of $\mathrm{CaCO}_{3}$ with a relative error of $1.9 \%$ and a relative standard deviation of $9.2 \%$.

Data from local authorities represent the calcium content of water at the distribution point whereas water samples measured at the laboratories represent calcium content at the drinking point. When possible samples from the same location source and analysed by the same methodology were aggregated and the mean and standard deviation was reported.

We also reported the calcium content described in the nutritional label of bottled waters commercially available in the Argentina. The period of data collection was between the years 2010 and 2018 .

The contribution of water from different sources to calcium recommendations was made taking into account one litre of water per day and a calcium recommendation for adults of $1000 \mathrm{mg}$ per day [30].

\section{Results}

We received information of water calcium concentrations from seven provincial water authorities that were classified as from supply systems: Water Control Agency of Buenos Aires (OCABA), Aguas Santafesinas Sociedad Anónima, Aguas Cordobesas, Federación Misionera de Cooperativas de Agua Potable, Aguas de Corrientes Sociedad Anónima, Obras Sanitarias San Juan Sociedad del Estado and Obras Sanitarias de Tierra del Fuego that provided data from 42 municipalities (Fig. 1).

We also had data from 184 samples remitted at the UNR from 72 municipalities of eleven provinces and 75 samples remitted at the UNLP from 34 municipalities of three provinces (Figs. 2, 3). Of the 184 samples remitted at the UNR 143 were from supply systems and 41 from private wells whereas of the 75 samples remitted at the UNLP, 14 were from supply systems and 61 from private wells.

Calcium concentrations of water provided by local authorities ranged from 6 to $105 \mathrm{mg} / \mathrm{L}$, we were not able to average these values as in some cases data provided was already aggregated (Fig. 1, Additional file 1: TableS1). Mean calcium content of the water samples remitted at the laboratories was $15.8(\mathrm{SD} \pm 13.2) \mathrm{mg} / \mathrm{L}$ ranging from 5.2 to $69.2 \mathrm{mg} / \mathrm{L}$ in UNLP and $13.1(\mathrm{SD} \pm 10.0) \mathrm{mg} / \mathrm{L}$ in UNR ranging from 0.0 to $43.9 \mathrm{mg} / \mathrm{L}$ (Additional file 1 : TableS2, S3 and S4). Water samples from supply system remitted at the UNLP had a mean calcium value of $19.0(\mathrm{SD} \pm 16.8)$ whereas those remitted at the UNR had a mean calcium value of $12.9(\mathrm{SD} \pm 8.8)$. Water samples from private wells remitted at the UNLP had a mean calcium value of $15.0(\mathrm{SD} \pm 12.3)$ whereas those remitted at the UNR had a mean calcium value of $13.9(\mathrm{SD} \pm 13.4)$ (Additional file 1: TableS4). 


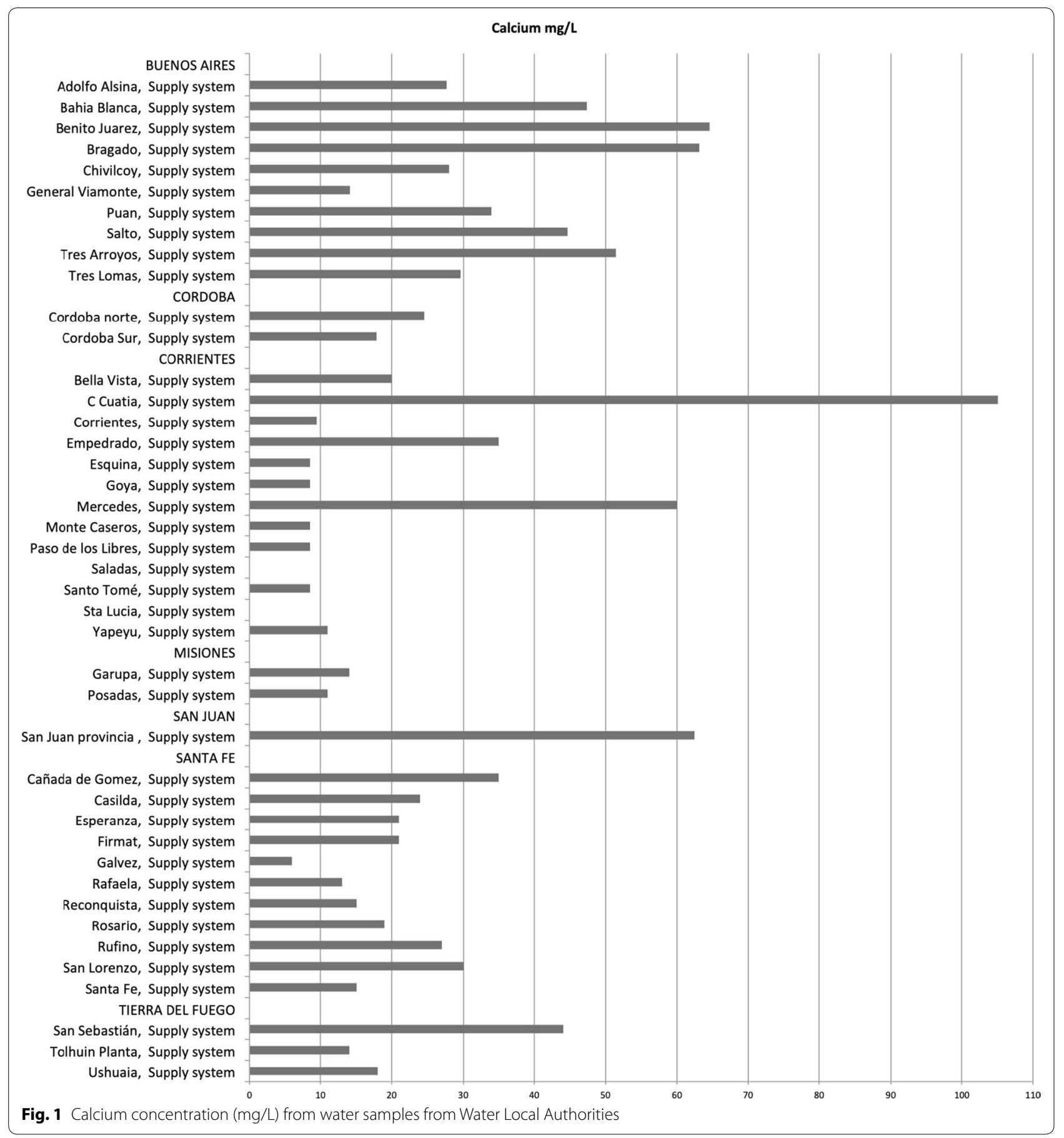

There were only six samples of water from local authorities that had calcium levels above $50 \mathrm{mg} / \mathrm{L}$, three from the province of Buenos Aires (Benito Juarez, Bragado and Tres Arroyos), two from Corrientes (Curuzú Cuatiá and Mercedes) and one from San Juan (Fig. 1, Additional file 1: TableS1). Only one sample remitted at the UNLP had calcium levels above $50 \mathrm{mg} / \mathrm{L}$ whereas none of the samples remitted at UNR had levels above $50 \mathrm{mg} / \mathrm{L}$ (Figs. 2, 3, Additional file 1: TableS2, S3).

We found nine brands of still bottled water. The calcium values reported in the nutritional labels ranged from 11.5 to $80 \mathrm{mg} / \mathrm{L}$. Only two labels reported calcium concentrations above $50 \mathrm{mg} / \mathrm{L}$ and none above $100 \mathrm{mg} / \mathrm{L}$ (Additional file 1: Table S5). 


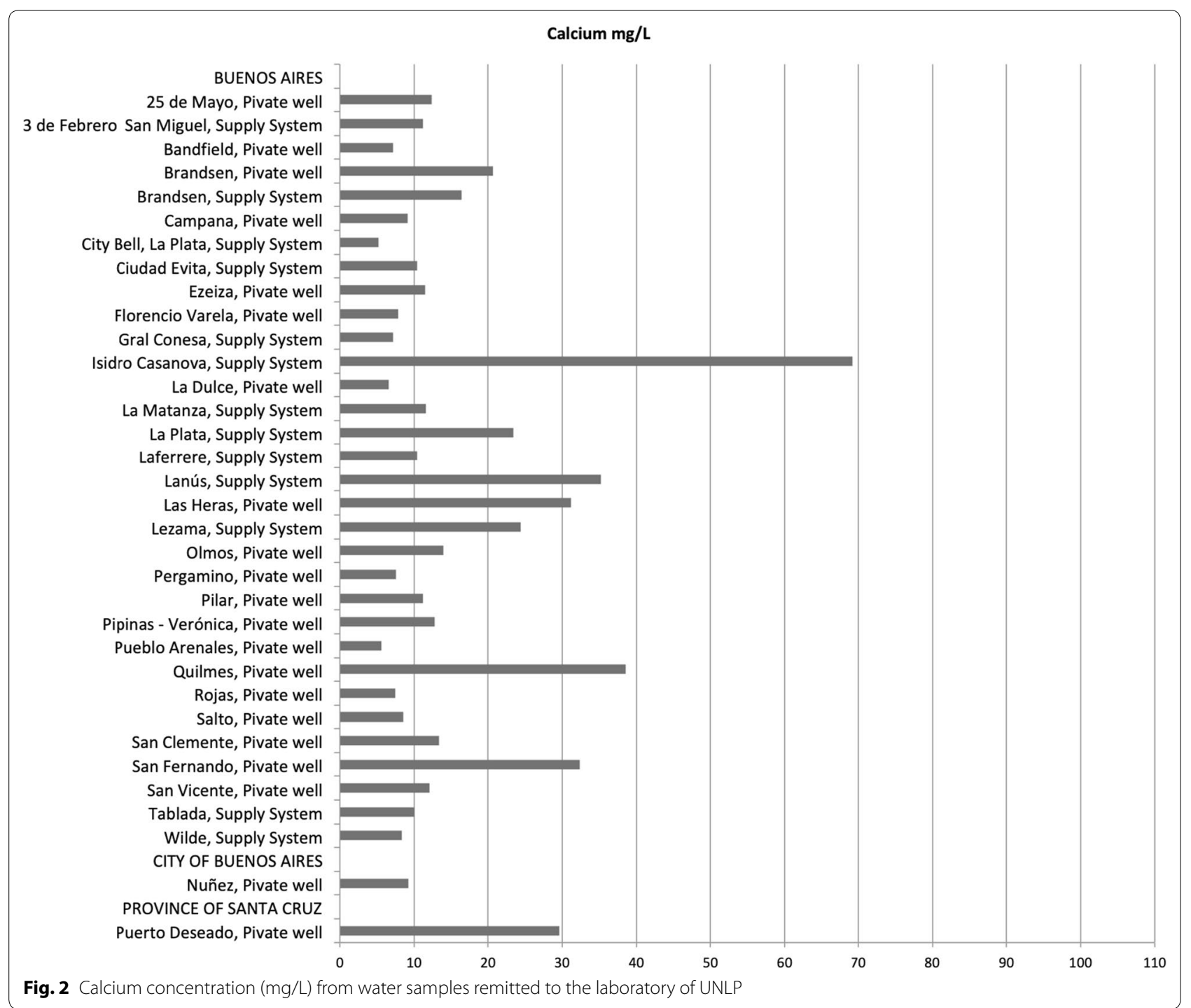

Taking into account a dietary recommendation of $1000 \mathrm{mg}$ of calcium a day, the mean calcium concentrations found in the water samples remitted at the UNR and UNLP would represent from 1.3 to $1.9 \%$ of the recommended calcium daily values per litre of water consumed. Calcium concentrations reported by local authorities could provide between 0.6 and $10.5 \%$ of the recommended calcium daily values per litre of water consumed.

On the other hand, the amount of calcium found in bottled waters could provide between 1.2 and $8 \%$ of recommended daily values per litre of water consumed (Additional file 1: TableS5).

\section{Discussion}

This article describes the calcium content of tap and commercially available drinking waters from Argentina.
Data were obtained from local authorities representing calcium levels at the distribution point, from samples remitted and analysed in two public laboratories and from data of nutritional labels of commercially available bottled waters representing calcium levels at the drinking point. With a few exceptions, most tap or commercially available bottled waters had calcium levels well below $50 \mathrm{mg} / \mathrm{L}$. The samples analysed at the laboratories had a mean calcium level of $15.8(\mathrm{SD} \pm 13.2) \mathrm{mg} / \mathrm{L}$ for UNLP and $13.1(\mathrm{SD} \pm 10.0) \mathrm{mg} / \mathrm{L}$ for UNR with similar calcium values between those from supply systems and those from private wells. The calcium content in water presented in this study shows high variability. Although samples are all from drinking water, water sources and treatment received were different and this can explain the variability. Even this variability, most samples had very little calcium concentration and the contribution to 


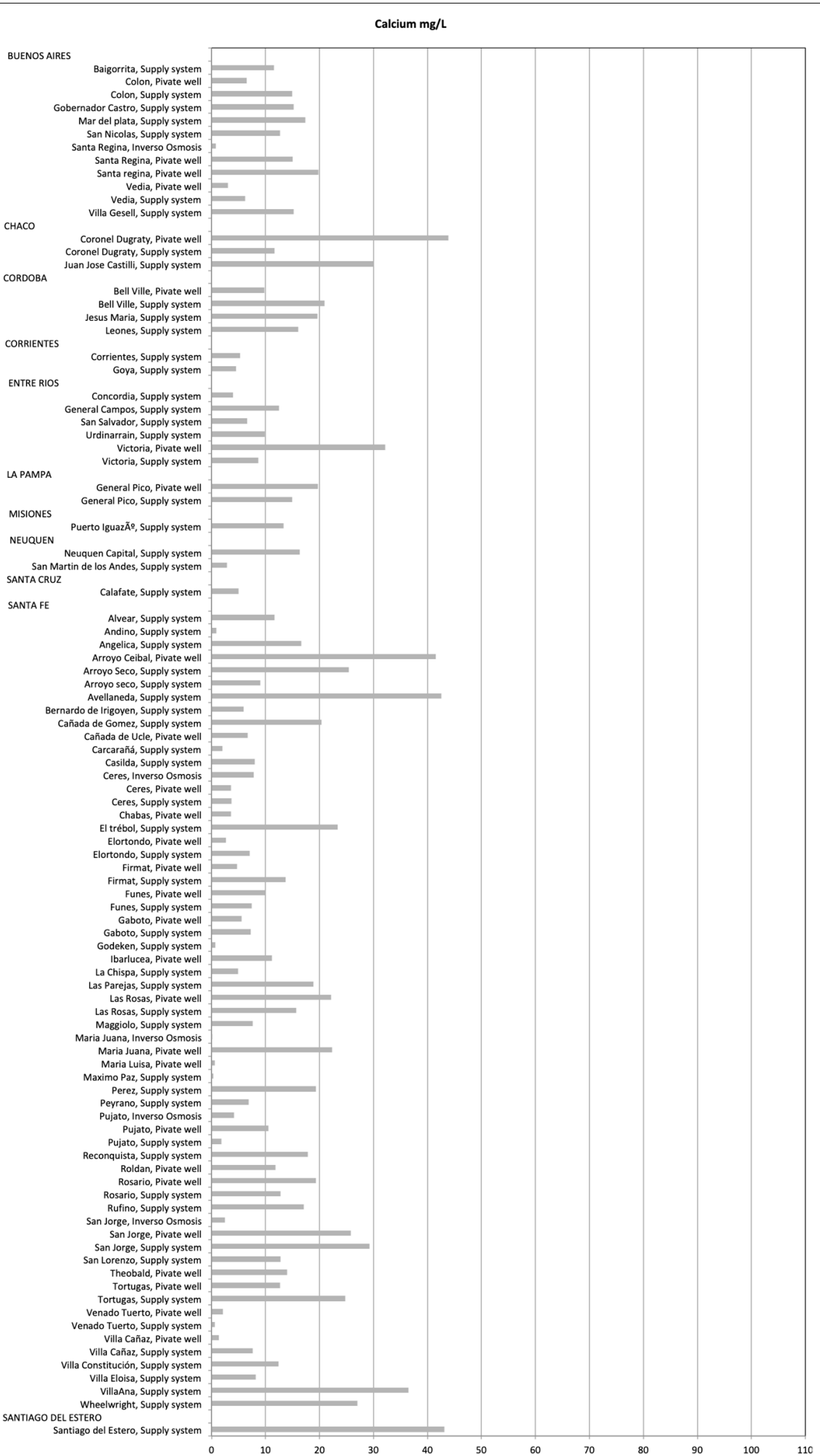

Fig. 3 Calcium concentration $(\mathrm{mg} / \mathrm{L}$ ) from water samples remitted to UNR 
dietary intake seems to be marginal. The intake of a litre of tap water from samples analysed in our study would provide in average between 1.3 and $1.9 \%$ of the recommended daily calcium values for an adult, whereas the average calcium content of water provided by local authorities would provide an average of $2.8 \%$ and that from bottled water between 1.2 to $8.0 \%$ of the recommended daily calcium values for an adult.

An article describing mineral content of waters from the United States shows an average of $34 \mathrm{mg} / \mathrm{L}(\mathrm{SD} \pm 21)$ from tap waters of surface sources $(n=36)$, of $52 \mathrm{mg} / \mathrm{L}$ $(\mathrm{SD} \pm 24)$ from tap water of ground sources and of $100 \mathrm{mg} / \mathrm{L}(\mathrm{SD} \pm 125)$ from mineral waters [6]. Information from Spain shows an average calcium concentration of public drinking waters of $38.9( \pm 32.4) \mathrm{mg} / \mathrm{L}$ and for mineral water was $39.6 \mathrm{mg} / \mathrm{L}$ [31]. The calcium content of tap water and commercially available mineral bottled waters we present seem to be lower than those reported in the United States and Spain.

Water consumption is regularly omitted in dietary intake surveys and not all chemical composition tables report calcium content of water. The information reported in this article could be used in dietary surveys to estimate the calcium provided from drinking water in Argentina.

Due to the good bioavailability of calcium in water, rich calcium waters would be a good option to increase calcium intake. One review reports that water bioavailability was $23.8 \%$ with a $248 \mathrm{mg}$ calcium load, however with lower loads bioavailability reached $47.5 \%$ [30] As water is usually drank thorough the day, the calcium load is spread and this can optimise calcium absorption.

There is evidence from epidemiological studies of an inverse relationship between water hardness and hypertension and also cardiovascular mortality [16-18]. In this way water hardness, which is determined by minerals in water, mainly calcium and magnesium, could improve health [19].

Taking into account the low calcium intake in many parts of the world and its consequences on health, regulations to improve calcium content of drinking water could help increasing calcium intake without changing dietary habits and consequently improve the health.

\section{Conclusion}

Calcium concentrations found in tap and commercially available bottled waters in Argentina are negligible to significantly improve the calcium intake of the population. In view of the health benefits of adequate calcium intake, the low calcium intake in several regions of the world, increasing calcium of tap and commercially available bottled waters could be an alternative to universally and equitable improve calcium intake. Strategies to assess and test the feasibility to increase calcium content of water need to be developed.

\section{Limitations}

- One of the limitations of this article is that the calcium content of water presented is not representative as it comes from 14 provinces of the 23 provinces in the country with no sampling methodology used or stated.

- Another limitation is that we do not have the methodology used to determine calcium values of data provided by local authorities nor the methodology used for measuring calcium concentration of commercially bottled waters.

- Although the methodologies used to determine calcium concentration of water by laboratories was different, both are accurate and recommended by the Standard Methods for the Examination of Water and Wastewater [29].

\section{Supplementary information}

Supplementary information accompanies this paper at https://doi. org/10.1186/s13104-020-05308-7.

Additional file1: TableS1. Calcium content in tap water from cities in Argentina. Data provided by water local authorities. Tables2. Calcium content in tap water from analysed by the Laboratorio de Ingeniería Sanitaria National University of La Plata UNLP. Table S3. Calcium content in tap water from analysed by the Bone Biology Laboratory of the National University of Rosario (UNR). Table S4. Samples of water available. Sources UNLP (Universidad Nacional de la Plata); UNR (Universidad Nacional de Rosario). Table S5. Percentage of the daily calcium recommendations taking into account 1000 mg per day and 1, 1.5 and 2 litres of daily water intake of commercially available water bottles.

\section{Abbreviations}

ENNyS: National Nutrition and Health Survey of Argentina; UNR: National University of Rosario; UNLP: National University of La Plata; EDTA: Ethylenediaminetetraacetic acid; OCABA: Water Control Agency of Buenos Aires; SD: Standard deviation.

\section{Acknowledgements}

We would like to thank Liliana Aranibar and Mariano Barberena for their help in the first steps of this work.

\section{Authors' contributions}

GC: Research idea generation, protocol development, data analysis and report write up, ML, NMi, NMa, MLu: participated data collection and analysis, JB, AR AP: involved in report writing and manuscript preparation. All authors read and approved the final manuscript.

\section{Funding}

This research was funded by Bill \& Melinda Gates Foundation Grant number OPP1190821.

\section{Availability of data and materials}

All data generated or analysed during this study are included in this published article and its Additional file 1. 
Ethics approval and consent to participate Not applicable.

\section{Consent for publication}

Not applicable.

\section{Competing interests}

The authors declare that they have no competing interests.

\section{Author details}

${ }^{1}$ Department of Mother and Child Health Research, Institute for Clinical Effectiveness and Health Policy (IECS-CONICET), Emilio Ravignani 2024 Buenos Aires, Argentina. ${ }^{2}$ Departamento de Salud, Universidad Nacional de La Matanza (UNLAM), 1754 San Justo, Argentina. ${ }^{3}$ Bone Biology Laboratory, School of Medicine, Rosario National University, 2000 Rosario, Santa Fe, Argentina. ${ }^{4}$ Centro de Investigaciones del Medio Ambiente CIM, UNLP-CONICET, Calle 47 esquina 115, La Plata, Argentina. ${ }^{5}$ Instituto de Desarrollo E Investigaciones Pediátricas "Prof. Dr. Fernando E. Viteri" Hospital de Niños "Sor María Ludovica de La Plata (IDIP), Ministerio de Salud/Comisión de Investigaciones Científicas de La Provincia de Buenos Aires, La Plata, Argentina.

Received: 28 May 2019 Accepted: 25 September 2020

Published online: 02 October 2020

\section{References}

1. Atlas Ambiental de Buenos Aires, Agencia de Protección Ambiental. https ://www.agencia.mincyt.gob.ar/frontend/agencia/post/827.

2. Heaney RP, Dowell MS. Absorbability of the calcium in a high-calcium mineral water. Osteoporos Int. 1994;4(6):323-4. https://doi.org/10.1007/ BF01622191.

3. Morr S, Cuartas E, Alwattar B, Lane JM. How much calcium is in your drinking water? A survey of calcium concentrations in bottled and tap water and their significance for medical treatment and drug administration. HSS J. 2006;2(2):130-5. https://doi.org/10.1007/s11420-006-9000-9.

4. Martinez-Ferrer A, Peris P, Reyes R, Guanabens N. Intake of calcium, mag nesium and sodium through water: health implications. Med Clin (Barc) 2008;131(17):641-6.

5. Djellouli HM, Taleb S, Harrache-Chettouh D, Djaroud S. Physicochemical quality of drinking water in Southern Algeria: Study of excess mineral salts. Cah Sante. 2005;15(2):109-12.

6. Azoulay A, Garzon P, Eisenberg MJ. Comparison of the mineral content of tap water and bottled waters. J Gen Intern Med. 2001. https://doi.org/10. 1111/j.1525-1497.2001.04189.x.

7. Kressel G. Bioavailability and solubility of different calcium-salts as a basis for calcium enrichment of beverages. Food Nutr Sci. 2010. https://doi. org/10.4236/fns.2010.12009.

8. Greupner T, Schneider I, Hahn A. Calcium bioavailability from mineral waters with different mineralization in comparison to milk and a supplement. J Am Coll Nutr. 2017;36(5):386-90. https://doi.org/10.1080/07315 724.2017.1299651.

9. Hofmeyr GJJ, Seuc AHH, Betrán APP, et al. The effect of calcium supplementation on blood pressure in non-pregnant women with previous pre-eclampsia: an exploratory, randomized placebo controlled study. Pregnancy Hypertens. 2015;5(4):273-9. https://doi.org/10.1016/j.pregh y.2015.04.001

10. Cormick G, Ciapponi A, Cafferata MLML, Belizán JMJM. Calcium supplementation for prevention of primary hypertension. Cochrane database Syst Rev. 2015. https://doi.org/10.1002/14651858.CD010037.pub2.

11. Prezioso D, Strazzullo P, Lotti T, et al. Dietary treatment of urinary risk factors for renal stone formation. A review of CLU Working Group. Arch Ital di Urol e Androl. 2015;87(2):105-20. https://doi.org/10.4081/aiua.2015.2.105

12. Heaney RP. Calcium supplementation and incident kidney stone risk: a systematic review. J Am Coll Nutr. 2008;27(5):519-27. https://doi. org/10.1080/07315724.2008.10719734

13. Onakpoya IJ, Perry R, Zhang J, Ernst E. Efficacy of calcium supplementation for management of overweight and obesity: Systematic review of randomized clinical trials. Nutr Rev. 2011;69(6):335-43. https://doi.org/10. 1111/j.1753-4887.2011.00397.x.

14. Chen C, Ge S, Li S, Wu L, Liu T, Li C. The effects of dietary calcium supplements alone or with vitamin D on cholesterol metabolism. J Cardiovasc Nurs. 2017;32(5):496-506. https://doi.org/10.1097/JCN.000000000000037 9.

15. Heaney RP. Calcium intake and disease prevention. Arq Bras Endocrinol Metabol. 2006. doi: S0004-27302006000400014[pii].

16. Yousefi M, Najafi Saleh $H$, Yaseri M, Jalilzadeh M, Mohammadi AA. Association of consumption of excess hard water, body mass index and waist circumference with risk of hypertension in individuals living in hard and soft water areas. Environ Geochem Health. 2019. https://doi.org/10.1007/ s10653-018-0206-9.

17. Kožíšek F. Health significance of drinking water calcium and magnesium. https://www.szu.cz/uploads/documents/chzp/voda/pdf/hardness.pdf.

18. Sengupta P. Potential health impacts of hard water. Int J Prev Med. 2013;4(8):866.

19. Thomas MP. Calcium and magnesium in drinking-water: public health significance. Int J Environ Stud. 2010;67(4):612-3. https://doi. org/10.1080/00207230903208415.

20. Balk EM, Adam GP, Langberg VN, et al. Global dietary calcium intake among adults: a systematic review. Osteoporos Int. 2017;28(12):3315-24. https://doi.org/10.1007/s00198-017-4230-x.

21. Standing Committee on the Scientific Evaluation of Dietary Reference Intakes, Food and Nutrition Board Institute of Medicine. Dietary reference intakes for calcium, phosphorus, magnesium, vitamin $\mathrm{d}$, and fluoride CHAPTER 6. In: Dietary reference intakes for calcium, phosphorus, magnesium, vitamin d, and fluoride. ; 1997. doi: https://doi. org/10.1111/j.1753-4887.2004.tb00011.x

22. Merialdi M, Mathai M, Ngoc NTN, et al. World Health Organization systematic review of the literature and multinational nutritional survey of calcium intake during pregnancy. Fetal Matern Med Rev. 2005;16(2):97121. https://doi.org/10.1017/S0965539505001506.

23. Cormick G, Betrán AP, Romero IB, et al. Global inequities in dietary calcium intake during pregnancy: a systematic review and meta-analysis. BJOG An Int J Obstet Gynaecol. 2018. https://doi.org/10.1111/1471-0528.15512.

24. Board FAN. Institue of medicine dietary reference intakes. Nutr Rev. 2004;62(10):400-1. https://doi.org/10.1111/j.1753-4887.2004.tb00011.x.

25. Ministerio de Salud de la Nación. Encuesta Nacional de Nutrición y Salud. https://www.extensioncbc.com.ar/wp-content/uploads/ENNyS-2007.pdf. 2007.

26. Ministerio de Justicia y Derechos Humanos de la Nación A. Ley 26221. Agua Potable Y Desagues Cloacales. Buenos Aires: Congreso De La Nacion Argentina; 2007:1. https://servicios.infoleg.gob.ar/infoleglnternet/verNo rma.do?id $=125875$

27. Centro de Endocrinología Experimental y aplicada. Tabla de Composición Química de Alimentos. Buenos Aires; 1995.

28. Ministerio de Salud de la Nación Argentina. Sistema de Análisis de Registro de Alimentos (SARA). 2018. https://datos.dinami.gov.ar/sara/.

29. Apha, Water Environment Federation, American Water Works Association 1999 standard methods for the examination of water and wastewater (Part 4000-6000) Stand Methods Exam Water Wastewater ISBN9780875532356

30. Böhmer H, Müller H, Resch KL. Calcium supplementation with calciumrich mineral waters: a systematic review and meta-analysis of its bioavailability. Osteoporos Int. 2000;11(11):938-43. https://doi.org/10.1007/s0019 80070032.

31. Vitoria I, Maraver F, Ferreira-Pêgo C, Armijo F, Moreno Aznar L, Salas-Salvadó J. The calcium concentration of public drinking waters and bottled mineral waters in spain and its contribution to satisfying nutritional needs. Nutr Hosp. 2014. https://doi.org/10.3305/nh.2014.30.1.7491.

\section{Publisher's Note}

Springer Nature remains neutral with regard to jurisdictional claims in published maps and institutional affiliations. 